\title{
An annotated bibliography on recordkeeping practices within Pacific churches
}

by

\section{Suliana Grace Vea}

\begin{abstract}
Submitted to the School of Information Management,
Victoria University of Wellington in partial fulfilment of the requirements for the degree of Master of Information Studies
\end{abstract}


An annotated bibliography

on

recordkeeping

practices

within Pacific

churches

INFO 580 Research Project

Suliana Vea 


\section{Acknowledgements}

First and foremost, I would like to give thanks, praise and glory to God for giving me the strength and knowledge to complete this work. There were many ups and downs in the process of putting this together, but I strongly believe that:

"With God all things are possible"- Matthew 19:26.

I would like to acknowledge and give a massive MALO 'AUPITO (thank you) to my supervisor Gillian Oliver for her constant support, and encouragement. Your generosity and knowledge has benefited me immensely. Thank you for bearing with me.

I would also like to acknowledge Pacific Studies lecturer, Teresia Teaiwa. Thank you for your inspiration and guidance for me to eventually pursue this area of study along with David Kukutai-Jones and Nicola Frean. Malo 'aupito.

Last but not least, an enormous thank you, thank you, thank you to all my family and friends for your continuous support, love, prayers and food. A special thank you to my father for making me reconsider the completion of this paper (in a positive light ()), my mother for putting up with my tantrums and my uncle for always giving me the time of day.

'Ofa lahi atu kiate kimoutolu hono katoa. 


\section{Abstract}

This bibliography focuses on recordkeeping in Pacific churches. It is organised into the following sections: current recordkeeping practices in the Pacific, archives in the Pacific, recordkeeping practices within churches in general, remittances, loan sharks and debt. It also covers news articles reporting instances of the abuse of resources in the Pacific church context. This annotated bibliography will assist with future research investigating the recordkeeping practices of Pacific churches. This is an area that needs investigating as Pacific families donate enormous amounts of money to the churches they belong to. 


\section{Table of Contents}

$\begin{array}{ll}\text { Abstract } & 3\end{array}$

$\begin{array}{lr}\text { Introduction } & 5\end{array}$

Bibliographic Gap 5

Purpose 5

Scope 5

Audience 6

Dissemination 6

Furthermore $\quad 6$

$\begin{array}{lr}\text { Bibliographic Annotations } & 8\end{array}$

Recordkeeping in the Pacific 8

$\begin{array}{ll}\text { Archives in the Pacific } & 10\end{array}$

$\begin{array}{ll}\text { Recordkeeping within Churches } & 16\end{array}$

$\begin{array}{ll}\text { Remittances } & 20\end{array}$

Loans and Debt 24

News Articles from the last 11 years 26

$\begin{array}{ll}\text { Conclusion } & 34\end{array}$

$\begin{array}{ll}\text { Index } & 35\end{array}$

$\begin{array}{ll}\text { References } & 37\end{array}$

Bibliography $\quad 45$ 


\section{Introduction}

In Pacific communities it is not surprising to hear of a church minister taking off with the churches money, or a small group of people playing a part in embezzling money from the community. This does not only occur in Pacific communities but Pacific people have one of the highest rates of loan shark participation in New Zealand and heavily rely on remittances from family members overseas (Macpherson \& Macpherson, 2011). One of the needs of this money is for the church and it is only fair that the money being loaned should be used appropriately by the church. There are cases when it has not. One of the ways to prevent the misuse of money and church resources is to have good recordkeeping practices.

Recordkeeping is "making and maintaining complete, accurate and reliable evidence of business transactions in the form of recorded information" (Standards Australia1996, pt. 1, p. 7, 4.19 in Kennedy \& Schauder, 1998, p.9). It is important to maintain who is accountable for what and how, which in turn helps those in charge or a part of the decision making process make the right decisions with the right records and resources in the functioning of the church.

\section{Bibliographic gap}

At this moment, the academic and professional literature about record keeping practices in the context of Pacific peoples is minimal. The materials available are not in depth but do mention the lack of good record keeping practices in these countries. This is the first attempt at compiling an annotated bibliography for the area of recordkeeping in not only the Pacific but also Pacific churches and one that is very necessary for today due to the reports of corruption and misuse of finances in Pacific churches not only occurring in the past but also in the present day.

\section{Purpose}

The islands of the South Pacific have one of the lowest and poorest recordkeeping practices/procedures in the world. Perhaps this is due to the lack of understanding and importance of good recordkeeping practices which leads to corrupt behavior and abuse of resources. In regards to the context of the church, this annotated bibliography provides an outlook on what has been happening within Pacific churches in relation to the use of money and financial and administrative records, where this money is coming from for donations, the pressure and effects of trying to raise donations on these Pacific families and how the knowledge and practice of good recordkeeping principles can ensure their donations are not misused.

\section{$\underline{\text { Scope }}$}

Due to this bibliography being the first of its kind, it is crucial to include everything related to the area of recordkeeping practices within Pacific churches. Churches need money and Pacific families are known to gift enormously to the church (Connell \& Conway, 2000) therefore it is important to explore where this money 
originates from. Origins are usually from remittances and at times loan sharks, leading these families into debt. It is vital to include archives in this bibliography as they are in a similar state with recordkeeping - still very much in their beginning stages in the Pacific. News articles have been included in this bibliography as they are evidence of what is happening out there in the Pacific churches. Only those articles published between 2002 and 2013 have been included. The geography which this bibliography focuses on is that defined by the Ministry of Pacific Island Affairs (MPIA) of Pacific people in New Zealand having links to Tonga, Fiji, Samoa, Tokelau, Nive, Cook Islands, Tuvalu, Kiribati, Vanuatu, Papua New Guinea, the Solomon islands and the small states in Micronesia (Tanielu \& Johnson, 2013, p.7).

I do include a few resources from Australia and America just to acknowledge similarities of the church situations but do not focus on them.

\section{$\underline{\text { Audience }}$}

The intended audience for this annotated bibliography are researchers or community members interested in recordkeeping practices within Pacific church bodies whether it is over in these small Pacific islands, here in New Zealand or in a specific city, such as Auckland or Wellington.

Although this is intended for researchers, I do hope to gain the attention of Pacific affiliated community and church leaders so that they are aware of how important good recordkeeping practices are in the functioning of the church but also for the community in general.

\section{Dissemination}

The promotion of this annotated bibliography can be through informative meetings with various Pacific community groups and/or their leaders, setting up a seminar through the Pacific Studies department at the Victoria University of Wellington and of course the use of social media to raise awareness of the issues mentioned in here. An approach could be made to the Ministry of Pacific island Affairs (MPIA) to gain interest and encourage research in this area to help Pacific communities.

Repositories for this bibliography would be the Victoria University of Wellington's Research Archive and possibly MPIA.

\section{Furthermore}

This annotated bibliography gives future researchers the background information needed in order to carry out a thorough assignment exploring what the current recordkeeping practices are (if there are any) within Pacific churches. There is a very strong potential for future archival records to be discovered in these Pacific churches and for it to be kept to benefit future generations and in the keeping of social memory would be of great value. 
The future is bright for Pacific churches due to them being an unexplored avenue in the area of archives and records management. For them to get involved with archives, it would be a great way of preserving their history.

It would be great to see what future developments occur as a result of this momentary examination and how it can benefit not only the Pacific community but also the information studies sector. 


\section{Bibliography Entries and Annotations}

The overall structure of the bibliography uses the following categories;

recordkeeping in the Pacific, archives in the Pacific, recordkeeping within churches, remittances, loan sharks and debt and news articles from the last 11 years. Within these headings, entries are presented in alphabetical order by author, where there are multiple entries per author these are arranged chronologically.

\section{Recordkeeping in the Pacific}

There are many challenges and obstacles to overcome in order for "good" recordkeeping practices to be a part of everyday life in many nations in the Pacific. These hindrances are often due to the lack of consistency and importance in the government and business sectors as well as the lack of its use.

Crookston, M. (2011). Raising the standard of recordkeeping in the Pacific: The PARBICA recordkeeping for good governance toolkit. Comma, 2011 (2): International Journal on Archives, 111-121.

This toolkit was designed to help those in the Pacific to have some form of recordkeeping practice but is now being used globally. In contrast to the international standards available, it was decided that this toolkit be designed in a way that can actually be applied in the Pacific. There were many issues when putting this toolkit together such as language, and training and education but they are all aspects that have been covered in order to make this toolkit a successful one.

Cunningham, A., \& Wareham, E. (2011). Introduction communities of memory: Ideas from the islands on refiguring archival identities. Comma, 2011 (1): International Journal on Archives, 1-4.

The authors provide a brief introduction into the way archives were from the beginning of time in the Pacific. Colonial administrators and missionaries relied heavily on the written works whereas the people in the Pacific were not so familiar with writing things down as they were more reliant on word of mouth - talking, speaking and memory in keeping stories alive. This is why archives are not so active or depended upon in the Pacific and are not as well developed as they are in the Western world. Keeping the memory of the past through oral tradition is fast declining due to the availability and ready use of technology. The memory of the human mind has been replaced with the memory of SD cards and memory sticks which in turn store what the human mind use to.

Hoyle, M., \& Millar, L. (2004). The challenge of records and archives education and training in the pacific. Archives \& Manuscripts, 32 (2), 114-141. 
Hoyle \& Millar mention a number of issues in regards to the challenge of records and archives education training in the Pacific. A few they mention are ones already pointed out in other articles such as the complexity of the government, the development of technology and the capacity of the archive. The realities in education and training in the Pacific is that distance-based education is very challenging especially when motivation is lacking. There is also the diversity of the languages within the Pacific region which suggest that different administration systems are in place, e.g. French vs. English. Although the issues are abundant, it is essential to have a basic training program to ensure the basics are covered.

Millar, L. (2003). Education and training for records and archives management in pacific island nations (a needs assessment and report prepared for PABRICA). Retrieved from PABRICA:

http://www.parbica.org/content/DistanceEducationProjectReport_tcm50-74752.pdf

Although this report was written ten years ago, there have been some slight improvements with what was found in here. The general use of technology was found to be low in the majority of the islands, and the existence of training and education were found to be majorly the basics. Lack of funds were also mentioned in this report and also how PABRICA is not recognized or given enough support in order to gain the means from financial aid. It does not help that the climate poses risks for archives and that the keeping of records infrequently takes place.

Tale, S. (2012). Canoeing in cyberspace: Recordkeeping in the Pacific - a Fiji case study. Comma, 2011 (1): International Journal on Archives, 45-50.

This short article gives insight into the case of Fiji and their recordkeeping practices. Fiji seems to have developed recordkeeping practices over the years of 1875 to 1970 (when they became independent), starting with the Wesleyan missionaries and their arrival into Fiji. Although this article is a short one, it is one of the positive stories within the Pacific region of the practice of recordkeeping and a rich history of it.

Wareham, E. (2012). From explorers to evangelists: Archivists, recordkeeping, and remembering in the Pacific Islands. Comma, 2011 (1): International Journal on Archives, 29-44.

Wareham delves into the beginnings of archiving and recordkeeping in the Pacific by starting with the explorers and evangelists that kept account of their travels but also colonized these islands and their recordkeeping influencing these micro states. She emphasizes the importance of knowing what the society is like culturally and politically prior to setting up a Western view of archives and its maintenance in not only the Pacific but those countries that are poor in terms of resources. Two key points are that archives and recordkeeping are not really supported by political bodies in the Pacific and there is a lack of cultural integration. 
Wickman, D. (2012). Recordkeeping legislation and its impacts: the PARBICA recordkeeping for good governance toolkit. Comma, 2011 (1): International Journal on Archives, 51-59.

Wickman gives a brief overview of the PABRICA (Pacific Regional Branch of the International Council on Archives) toolkit and its progress in the Pacific. Wickman writes about one part of the toolkit stating the importance of communicating and educating face to face rather than just giving a brochure for staff to read which is a great part of the toolkit as the Pacific people are keepers of oral history and orally was how they use to pass down songs, dances, ancestors etc. therefore to do something their way will be more effective for them and their learning.

\section{Archives in the Pacific}

In the Pacific, local people have little knowledge of archives and their purpose, although this is of a high importance for the nation's memories and heritage. The entries below give insight to the area of archives and its place or need of a place in the Pacific.

Conrad, A. C. (1967). The archives of Hawaii. The Journal of Pacific History, 2, 191197.

On the other side of the Pacific is Hawai'i, a part of the United States of America but one with colonial and post-colonial problems similar to their Pacific neighbours. The Archives of Hawai'i surpasses Fiji's National Archive in terms of longevity and formation. Conrad offers a very insightful, short history of how the archives came about and the establishment of the archives of Hawai'i. The holdings are very rare and are records of those that held power throughout generations in this nation. Although this article is one from the late 1960's it does explain how some records were not maintained and looked after properly as a result of the lack of staff and lack of expertise in this place at the time. That was the case then with the Hawai'i archives but is still valid today in other parts of the Pacific.

Cohen, A. (2011). Pacific Islands Association of Libraries and Archives (PIALA). In (EDITORS NAMES Eds.) Encyclopedia of Library and Information Sciences, (3rd ed. , pp. 4095-4105). Retrieved from Taylor \& Francis Online database.

This chapter goes into depth about the work of The Pacific Islands Association of Libraries and Archives (PIALA) in the Pacific. PIALA was formed in 1991 within the islands of Micronesia. The islands include the United States (US) Territory of Guam, and the former U.S. Trust Territory entities of the Commonwealth of the Northern Mariana Islands (CNMI); the Federated States of Micronesia (FSM) comprising the states of Chuuk, Kosrae, Pohnpei and Yap; the Republic of the Marshall Islands; and the Republic of Palau. This association has spread to throughout the Pacific and provides human networks for the museum, archive and library professions. There is 
the sharing of resources and knowledge through the conferences held by this organisation and the enrichment of the training programs provided to develop these professions which is strongly needed in the Pacific.

Crookston, M. (2011). Record keeping for good governance in the Pacific: The work of the Pacific regional branch of the international council on archives. Archifacts, 73-83.

Crookston emphasizes the importance of collaboration and communication in this article. The toolkit he created (The PARBICA recordkeeping for good governance toolkit) has been incorporated easily into the majority of the Pacific nations with it being translated into French as well by the French to be used in their Africa in their small colonies over there. Crookston highlights the lack of good record keeping practices in the Pacific which results in government being unstable, with a lack of integrity and accountability which if was in place would offer good governance.

Cummins, H. G. (1978). The archives of the Free Wesleyan Church of Tonga. The Journal of Pacific History, 13(2), 102-106.

Cummins details the history of the Free Wesleyan Church of Tonga in Tonga. This archive contains a history from the beginning up until 1978. Cummins describes many records being lost over the time, which at one point was due to a person in charge refusing to be a part of a union and consequently failed to keep up with the records at the time. This shows the power a person in charge of records can have due to them deciding what goes and what does not which results in gaps in history. This article is a reminder of the historical ties between the missionaries and Pacific nations which should be recorded and preserved for future generations.

Gilliland, A., McKemmish, S., White, K., Lu, L., \& Lau, A. (2008). Pluralizing the Archival Paradigm: Can Archival Education in Pacific Rim Communities Address the Challenge?. The American Archivist, 71, 87-117.

This article points out the need for a Pacific voice, the need for the community within each Pacific nation to stand up and get involved with archives and recordkeeping. The lack of knowledge regarding archives and recordkeeping and its benefits to the community is one of the reasons why its practice is not so familiar in the Pacific. The lack of training and development among staff is again reiterated as well as the fact that educational institutes available to train these members are not close enough to home. All in all the findings in here imply that local and indigenous knowledge and practices should be included and integrated in the general education and practice of archives and recordkeeping.

Gordon-Clark, M. (2012). Paradise lost? Pacific island archives threatened by climate change. Archival Science, 12(1), 51-67.

We are reminded in this article of the weather conditions in the Pacific especially due to climate change which could result in cyclones, hurricanes and lately 
tsunamis in which archives can be destroyed. Other effects of climate change in the Pacific are an increase in sea levels, extreme weather events and their consequences (hurricanes, cyclones etc.), political and social upheaval and risks to national infrastructure of low-lying islands and nations. Consideration has to be given to determining where these archives will be stored physically due to these threats.

Kaima, S. (1999). Education and training for archivists and record keepers in the Pacific. Information Development, 15(1), 51-55.

The issues mentioned here are still relevant to today and what is currently happening in the Pacific. Kaima emphasizes the need for workshops and training and in regards to Papua New Guinea and their struggles specifics that are mentioned are the lack of management support, lack of legislation and education about archives and recordkeeping. Kaima concludes that there will only be developments "if and when there is nation-wide publicity and recognition of the importance of records for accountability purposes" (p.54).

Kaima, S.T. (2000). Rekot bilong masta: Archives and records management in Papua New Guinea. Information Development, 16(1), 37-43.

This article is a very important one and one that is relevant to the majority of the Pacific. Kaima explains the reason for the lack of records in Papua New Guinea and points out a very important aspect - that so much of the history of the people of the Pacific is written by outsiders but not so much by those within. This is because they did not see it as important to keep written records as everything was passed on orally and learning was done by observing. He also points out the lack of knowledge in regards to records and what to do with them, especially in the government sector where there are no proper procedures and guidelines results in the staff not knowing what to do. Kaima also points out the lack of education and knowledge in the archival and records management sector which helped in the downfall of the Archival institute.

Kempf, W. (2012). Promised land in the diaspora: Christian religion, social memory, and identity among Banabans in Fiji. Pacific Studies, 35(112), 90-1 18.

Social memory stands out in this article and it is appropriate to include here as that is what archival institutions hold - memories of people, events etc. Banabans originate from Ocean Island, a part of Kiribati in the North of the Pacific. They are a community which had to be evacuated under emergency from their island home due to the industrial mining operation that stripped the land, making it unfit for habitation. In the end they were relocated to Rabi Island, a part of the islands of Fiji. Each year they get together to hold a commemorating festival of how they ended up on Rabi Island, with speeches, songs and dance in action. Kempf mentions a song in this article which describes and assimilates the journey of the people of Banaba to Rabi Island comparing it with the Israelites in the bible and their journey to Canaan from Egypt. The mention of this song is a reminder of the oral history that is strong in the Pacific. Songs may be put on paper but are often just passed along 
through word of mouth. There are issues about preserving this for the future and is still very important for today, where technology is taking over this form of passing on history orally.

Maidment, E. (2001). Fiji museum archives and manuscripts collection. The Journal of Pacific History, 36 (2), 237-246.

This article contains a list of items from the Museum Archive that were microfilmed in 1999. Not much is mentioned in this article other than this project to transfer to microfilm the items listed but it is noted that during this process that parts of the illustrations had been removed or lost. Access to these microfilms are restricted in order to protect the interests of the Museum and in order to access them, researchers are required to get the written permission of the Registrar. It is shown through this article that the basic archival practices are in function here at the Fiji Museum in protecting their archival records.

Laracy, E., \& Laracy, H. (1979). Archives of the Catholic Diocese of Tonga. The Journal of Pacific History, 4(4), 221-224.

This contains a list of materials contained in this archive.

Laracy, E., \& Laracy, H. (1979). Archives of the Marist Province of Oceania. The Journal of Pacific History, 14 (4), 224-227.

This contains a list of materials contained in this archive.

McKemmish, S., Faulkhead, S., \& Russell, L. (2011). Distrust in the archive: Reconciling records. Archival Science, 11, 211-239.

This is a case study of the Koorie Aboriginal indigenous people of Victoria, Australia and their mistrust of archives. Due to the mental and physical abuse during the colonial times that these people faced, they are very wary of the Australian government and anything to do with it. This article looks at colonial and postcolonial implications that result in documentation of people in a way that the community they belong to may not agree with. The Koorie people want their side of the story told and the authors conclude that consideration should be given to the other sides of the story that has been documented by government archives. This is relevant to archives in the Pacific because it emphasises the need to consider the outlook of indigenous people, especially in post-colonial countries and to be flexible in the way things are done in order to accommodate the needs of the indigenous people about their heritage.

Miller, K.C. (2009). Sound ethics for data repositories: The selected Works of Kevin

C. Miller. Retrieved from http://works.bepress.com/kevin miller/4

Miller looks at the issue of digital sound recordings and access to them from "sourced communities" which he refers to as historically marginalized community groups or political minorities. There is also the issue of the digital divide, where these 
sourced communities cannot access a computer or internet in which to hear themselves and have a voice on the way they are represented. He also points out that it is often the researchers that mediate with the communities from whom they have sourced the sound recordings and that institution do not generally do this. This is relevant to archives in the Pacific because there are communities out there that allow researchers into their domain but do not have access to technology that will enable them to hear what has been recorded of their singing, voices of their ancestors etc. Each archival institute is different and has their own rules and regulations but it is important to acknowledge the voice of the communities which they have materials from.

Newman, J. (2012). Sustaining community archives. Comma, 2011 (1): International Journal on Archives, 89-102.

This article is useful for the consideration of the sustainability of archives and recordkeeping within the Pacific community. There is a very useful table consisting of characteristics indicating likely sustainability of community archives for example, the archive has a defined legal status, and authority and purpose and is committed to growth in terms of collections and users. Three factors were found in this study to be lacking in literature and they were the nature of the collections, the character of the archivist and external support for the sustainability of community archives.

Pawley, A. (n.d). The need for a Pacific languages archive. Retrieved from http://www.paradisec.org.au/Pawley\%20abstract.pdf.

Prawley argues for the need of a Pacific languages archive as the Pacific contains one quarter of the world's languages. He urges the need to preserve these diverse languages, especially the ones in Melanesia as there are fewer recordings than in Polynesia and Micronesia. Prawyley mentions the consequences of losing traditional languages with examples of the indigenous people of New Zealand, Australia and Hawai'i. Prawley also highlights the lack of funds and infrastructure for Pacific Island countries to preserve materials successfully and this is very worrying for all over the Pacific as vital materials can be lost because of these conditions.

Saunders. T \& Terrell, J. (2000). Pacific history bibliography 2000. The Journal of Pacific History, 35(3), 335-376.

This is a bibliography containing a list of works that may be of interest to Pacific Historians. There are also other versions available from 1990's to today.

Tale, S. (2012). Memory of the world: The Pacific perspective. Comma, 201 1(1): International Journal on Archives, 73-78.

This is a very informative article in regards to what is lacking in the Pacific, such as reasons as to why good archive and recordkeeping practices are prevented from being practiced. Key points mentioned include the lack of internet connectivity, lack of information management and lack of funding. These are important to be 
taken into account when considering the background of archives and records management in the Pacific. These may in turn have impacted on what is happening today in the Pacific communities in Wellington.

Thornley, A.W. (1977). Methodist mission papers in the National Archives of Fiji, Suva. The Journal of Pacific History, 12 (4), 202-204.

This article does not talk about the specific archival practices in this institution but describes the Methodist mission papers available here. This article is from the 1970's and shows Fiji as being one of the first to house a national archive in the South Pacific. It also shows them to be at the forefront of archives in the South Pacific in their time which still seems to be valid today.

Tough, A. G. (2012). Oral culture, written records and understanding the twentiethcentury colonial archive. The significance of understanding from within. Archival Science, 12(1), 245-265.

There are similarities in this case of the Africans and their treatment by the Europeans and some of the Pacific nations. There are issues of interpretation and understanding which is what happened here in New Zealand with the Treaty of Waitangi - a misinterpretation but could also relate to the Pacific with words being used in records that are no longer used today and the different writing formalities or language. Oral communication in the colonial administration is another focus of this article and that is similar to some of the Pacific where interviews and oral gatherings are being held so that periods of history can be retold or restated or corrected.

Wehner, M., \& Maidment, E. (1999). Ancestral voices: Aspects of archives administration in Oceania. Archives and Manuscripts, 27(1), 22-41.

This paper focuses on archives administration in Oceania. Wehner and Maidment concluded that indigenous input is very important in relation to the administration of archives and that the people themselves should have an opportunity to put their sides of the stories and maybe even correct what they may see as misleading conceptions about them from the experiences of the explorers and evangelists. This shows the heavy reliance on these written records not only by researchers but also by family members and historians.

White, L.K., \& Gilliland, J.A. (2010). Promoting reflexivity and inclusivity in archival education, research, and practice. The Library Quarterly, 80 (3), 231-248.

White and Gilliland believe that due to the frequent updates in cultural, social, political and technological phases, the traditional archival paradigm is no longer suitable. This requires a new paradigm to be developed so that it encompasses these changes and keeps up with them. This is relevant to archives in the Pacific as the authors use a case study of the University of California's Pacific Rim Program to find out what is happening in the Pacific in regards to archival education and to inspire research and other activities. The authors recognize that communities, 
groups, and individuals, especially indigenous ones now want to set up their own archival construction processes which include non-textual processes such as dance, song, and recitation. They also want to take control of their archival heritage which some are stored in archival and collecting institutions. White and Gilliland identify that these communities are bypassing traditional archival practices that they see as irrelevant and obstructive and are engaging in their own ways by using alternative channels such as social media outlets like blogging, Facebook etc. as well as video histories and documentary filmmaking.

\section{Recordkeeping within Churches}

Explored here will be just a handful of the findings on the practice of recordkeeping within churches in general globally. The Catholic Church is known to have a complex system of keeping their records and the Church of the Latter Day Saints (Mormon) has a comprehensive focus on personal records, regardless of religion or denomination, which is very helpful for family historians. Throughout history, records are known to be hidden within the church and at times require deciphering. The changing of technology has seen churches' needing to keep up, therefore careful consideration has to be applied to their recordkeeping practices especially now that keeping records electronically is common.

Basri, H.,\& Khalid, S.N.A. (2012). Examining accounting and accountability issues in religious context: Insights from literature. Aceh International Journal of Social Sciences, 1 (1), 24-31.

Basri \& Khalid outline the different types of literature which consider accounting and accountability issues in religious contexts. They discuss the complexity of conducting research on accounting and accountability in religious organizations due to what they state as "issues concerning the soul, which is not simply measured" (p. 26). They mention the work of Canning, 2000 urging the need for protocols in accountability for religious organizations. The authors also mention the work of Siino, 2004, that examined 548 Southern Baptist Churches. The outcome of this research experiment was that little was done to prevent the mishandling or exploitation of their funds and that written financial processes did not exist in more than 70 percent of the churches surveyed.

Cafardi, N. P. (1993). Discovering the Secret Archives: Evidentiary Privileges for Church Records. Journal of Law and Religion, 10(1), 95-120.

Cafardi looks into the secret archives within the Roman Catholic Church. There is a rule that all dioceses are to maintain secret archives, completely shut off and sealed. There are very strict rules about accessing these archives and only "the diocesan bishop or the apostolic administrator of the diocese in the absence of a bishop" can have access to these records. What is contained in these secret archives are: 
"(1) acts of criminal cases which concern matters of morals;

(2) the register of secret marriages;

(3) matrimonial dispensations in the non-sacramental internal forum;

(4) dispensation from impediment to orders;

(5) documents concerning loss of the clerical state;

(6) decrees of dismissal from religious institutes;

(7) document selected by the bishop in order to prevent scandal or damage to someone's good name (including priest personnel files)" (p. 98).

What this article illustrates is the existing secrecy of some churches, having their own protocols and agendas. This is a form of recordkeeping that is both advantageous as well as damaging for some churches.

Carmona, S., \& Ezzamel, M. (2006). Accounting and religion: a historical perspective. Accounting History, 11, 117-127.

This article is a very thought-provoking introduction into a historical perspective on the research of accounting and religion. The authors mention the lack of interest in the study of this field by academics, which was both surprising and not so surprising. The authors state that "accounting was seen as part of the profane world and, as such, its use in the church was viewed as an unwanted intervention into the world of the sacred. Accounting was marginalized, argued Laughlin, being simply entrusted with ensuring that sufficient revenues are generated to cover costs, and never used to question what was going on." (Carmona \& Ezzmael, 2006, p.20). Perhaps this was the view in the Pacific churches, not questioning the work of those in charge and with leadership positions as maybe that would mean they are questioning God.

Carnegie, G.D., \& Napier, C.J. (2012). Accounting's past, present and future: the unifying power of history. Accounting, Auditing \& Accountability Journal, 25(2), 328-369.

The authors set out to emphasize the importance of accounting's past, present and future and how it is vital to know accounting's past in order to move on from the present to the future. In this article we are shown the importance of accounting in history by allowing us a glimpse into the systems of the past, the monetary side but also the records side all pertaining to history within society, institutions, events, religions etc.

Evans, M.R. (2006). Recordkeeping practices in selected Atlanta area black churches. The University of North Carolina at Chapel Hill, ProQuest, UMI Dissertations Publishing.

Evans finds in her research that the materials found or shown were disorderly, poorly stored and in various locations within the church and in outside repositories. She also finds that there is minimal professional /formal practice relating to recordkeeping although the survey she conducted had the majority of the participants stating their feel for the importance of keeping records and its implication on society and written 
history. Evans brings up a number of issues with this investigation and they are numerous, for example; the need for some formal system to exist, churches should seek out professional guidance and try to better systemize current practices, archivists should reach out to local repositories and educators should place more emphasis on recordkeeping practices within their curriculum.

Irvine, H. (2004). Balancing money and mission in a local church budget. Accounting, Auditing \& Accountability Journal, 18(2), 211-237.

This article is very interesting in that it considers the church budget and church vision and the incorporation of the two. The church budget sets out what resources are available in order to promote or achieve the visions of the church or their goals. Irvine concludes in this research study that when accounts are kept up to date it provides a more positive outlook on accounting. Not only does it benefit the church but it also shows the realities of their financial situation in order to achieve the church vision. This shows how keeping account of the financial situation and sharing that knowledge allows less leeway for the abuse of resources.

Leardini, C., \& Rossi, G. (2013). Accounting and power in religious institutions: Verona's Santa Maria della Scala monastery in the Middle Ages. Accounting History, 18, 415-427.

Although this research looks at a monastery in Italy in the Middles Ages, the ideas presented can be applied to churches today. Accounting played a strategic part in underpinning both hierarchical and horizontal power dealings amid friars. The primary and secondary resources used as a basis for this article were from archival records, which show the impact archives have for future research and studies. Leardini \& Rossi note that expertise over accounting is a source of power. The possibility of recording facts and events via written entries, expedites the practice by which superiors hold subordinates accountable for their activities. Command over accounting grants those in the lower level of the hierarchy the aptitude to impact the movements of their seniors, allowing them to select what material to transfer and what to hide. How this relates to a church context is that, whoever is in charge of the accounting side or recordkeeping side has power to decide what will be recorded for the future and how and why.

McPhail, K., Gorringe, T., \& Gray, R. (2004). Accounting and theology: An introduction. Accounting, Auditing \& Accountability Journal, 17(3), 320-326.

The aim of this article is to skim the surface of accounting and theology and set the platform for future research into this study. The authors identify plenty of literature which will be very valuable for readers with no prior knowledge of the relationship between accounting and theology. 
Paisey, C., \& Paisey, N.J. (2011). Visibility, governance and social context: Financial management in the Pre-Reformation Scottish church. Accounting, Auditing \& Accountability Journal, $24(5)$, 587-621.

This article mentions an important part of the recordkeeping history within the church as well as emphasising society's social structure and especially the elite's part in dealing with records. The clergymen were said to have held power by controlling what was to be recorded and how. The elite had a say in this process too as they were able to manipulate the records and use them for their own benefit but did so in a very discreet way. This is very interesting and is a great connection to how records are or can be abused or used in an unfair way to benefit unethical behaviour. This type of behaviour is also common within Tongan churches.

Rixon, D., \& Faseruk, A. (2012). Secular tools and sacred goals: A case study of how Anglican priests are embracing management accounting and strategic planning. Journal of Business Diversity, 12(1), 19-32.

Rixon and Faesruk explore the part that management accounting and strategic planning play in helping churches to achieve their mission and strategic goals. Their results find that the priests are very accepting of these processes and do not reject them on the basis of their secular nature. It was often regarded as unholy to discuss and immerse oneself in worldly practices in handling money but this article shows that, that is no longer the case. Priests were very supportive due to the reliance they have on management accounting information to assist them in their decision making. The authors highlight the need of the priests for budget reports and their preference for reports over financial statements. This article shows the advantages of using secular tools to help the church in decision making processes as well as to achieve their mission and goals. This would be of great help to Pacific churches

Ryan, J. G. (2001). Irish Church Records: Their History, Availability, and Use in Family and Local History Research. Flyleaf Press: Dublin, Ireland.

This book depicts the role of the Irish church within society and what it can provide for historians and especially family researchers with what has been documented in the church records. The author points out a significant aspect of the history of Ireland which is interlinked with the history of the Irish churches as a result of religion being a political as well as spiritual aspect, since the $16^{\text {th }}$ century. This paper is a reminder of the strength of the ties between the Pacific nations and religion. Missionaries are the ones that kept records of interactions with these "savage" nations and were the ones that "saved their souls". It is often the journals and letters of these writers that are in demand for their depiction of these Pacific nations in the colonial contact era.

Seles, A. (2006). What are these among so many? Pre and post Vatican II recordkeeping. Archival Science, 6, 393-405. 
Seles offers an invigorating historical timeline of pre and post Vatican II recordkeeping. The changes in procedures within the hierarchy meant that, different people had different roles and this took the bishop/committees/ Archdiocese some adjusting to. Seles concludes with a call for more research into contemporary church recordkeeping practices as it is an area that is neglected by scholars.

Sweeney, S. (1986). Sheep that have gone astray?: Church record keeping and the Canadian archival system. Archivaria, 23, 54-68.

Recordkeeping within the church involved the vital mission of keeping count of church members. Although this article is somewhat dated, it does give an idea of what the church recordkeeping ideas were at the time of the study and illustrates that churches thought recordkeeping was important.

\section{Remittances}

Remittances play an important part in the daily lives of Pacific families where money is often sent back home to help in the general running of family homes. It is a major means of income for many but also heavily used for obligations of the family to the church, village, county and family events. Here is a selection of works on remittances. A restriction had to be put on what could be included due to the quantity of references found.

Boland, S., \& Doller, B. (2005). The economic significance of migration and remittances in Tuvalu, 1-37.

Boland and Doller describe the importance of the relationship between migration and remittances. Tuvaluans have a long history of migrating to and fro to neighbouring countries such as Kiribati, Ocean Island and Nauru especially in order to look for work. New Zealand also has a growing number of Tuvaluan migrants. They leave their homeland in order to seek work to support their families. These remittances are vital in the livelihood of Tuvaluans. Remittances from seafarers were also known to be substantial in Tuvalu and that line of work was often employed by those that had little education. Providing for their families by going out to sea meant being absent for 6-24 months at times. This shows the need to provide as a priority.

Borovnik, M. (2006). Working overseas: Seafarers' remittances and their distribution in Kiribati. Asia Pacific Viewpoint, 47(1), 151-161.

Borovnik describes the realities of this Pacific nation. Unemployment is high due to a number of reasons, one of them being the lack of jobs available for such a growing community as well as the lack of development. This report shows that both the immediate and extended families benefit greatly from remittances and heavily rely upon them, especially those living in the rural areas. These remittances cover the 
costs of everyday living for these families and are a major investment in the education of children. An interesting factor is how immediate families of seafarers try to reduce the obligation to their extended families by making the trip to the other side of the island to pick up their son (who works on the boats as a seafarer) instead of leaving it to their extended families to do so whom are closer.

Brown, R.P.C, \& Ahlburg, D.A. (1999). Remittances in the South Pacific. International Journal of Social Economics, 26 (1/2/3), 325-344.

Brown \& Ahlburg identify what remittances are used for in the Pacific such as repaying loans that were used for the financing of migrating overseas, consumption of food and clothing, construction materials for housing, investments, education and social purposes such as weddings, funerals etc. At the time of their survey, giving to the church was not highlighted as a significant use for remittances, although it was part of the social ones. What is interesting and is thoroughly depicted in this article are the developing stages of Tonga and Samoa. The use of remittances here shows what was important at the time. The research on remittances for at least the past eight years signifies the importance of the use of remittances for church donations. What this shows is a shift on the needs and wants of the people, as well as what their priorities are.

Brown, R. P. C., Connell, J. \& Jimenez-Soto, E. V. (2013). Migrants' Remittances, Poverty and Social Protection in the South Pacific: Fiji and Tonga. Wiley Online Library, 0-20.

There are many themes brought up in this article that are very relevant to remittances today. The authors found that the lower the level of poverty, the higher the remittances but also that the poverty levels are higher today compared to the last decade. Also highlighted is the reliance on migration and remittances for these two nations, showing that if it were not for them then the poverty rates would have doubled over the last decade. There are many positive outlooks in this article that make its inclusion in this bibliography imperative.

Connell, J., \& Conway, D. (2000). Migration and remittances in island microstates: A comparative perspective on the South Pacific and the Caribbean. International Journal of Urban and Regional Research, 24(1), 52-78.

Connell \& Conway highlight the significance of remittances to Pacific families not only for household consumption but for contributions to the church. It is repeated throughout this article that remittances are used for donations to the church, funding of a new church building, church maintenance, and income for pastors and other related activities. Connell \& Conway also remark on the social status of the remittance receiver and sender as being elevated in the community due to these giving to the church. Perhaps this is where the pressure to give gets out of hand by some families going too far and not sticking to only what they can give as they want to get that high "up there" social standing. I personally know that it can get very competitive with who gives the most and for what. 
Le De, L., Gaillard, G.C., \& Friesen, W. (2013). Remittances and disaster: A review. International Journal of Disaster Risk Reduction, 4, 34-43.

Le De, Gaillard \& Friesen discuss the impact remittances have when disaster strikes. The authors state that there is an increase in remittances during crisis events. The Pacific is included in this evaluation and the statements made about these people are that their economies are dependent on remittances and that there will be an increase of this should disaster strike. This was evident in the 2009 earthquake in Samoa which resulted in a tsunami damaging parts of the country significantly and killing almost 200 people. Fund raising initiatives were in full force after this from community and family members from abroad. This paper is a reminder of this codependant relationship between migrants and their families back home. The authors urge for further research to be conducted to identify strategies to be used when a crisis event occurs.

Marsters, E., Lewis. N., \& Friesen, W. (2006). Pacific flows: The fluidity of remittances in the Cook Islands. Asia Pacific Viewpoint, 47(1), 31-44.

A major point highlighted in this article was the Cook Islands dependency on foreign aid and their dependency on family over in New Zealand for remittances. This is also the case with other Pacific nations and it is very concerning, the amount of aid they receive and what will be asked of them later on, for accepting this aid. The tourism industry in the Cook Islands is a very strong one similar to their neighbouring counterparts Samoa and Fiji.

Macpherson, C., \& Macpherson, L. (2011). Churches and the economy of Samoa. The Contemporary Pacific, 23(2), 303-338.

Macpherson \& Macpherson go into meticulous detail in regards to how immersed Samoans are in the church and its place in their daily lives. This is a great example of what it is like in other Pacific countries such as Tonga and Fiji. There are instances of over donating therefore causing the need to borrow from extended family just to get by each day and get the necessities. This also leads to loans from financial institutions with very high interest. Overall, the authors point out the significance of remittances in not only for church purposes but as a main means of income for the families receiving them.

Poirine, B. (1997). A theory of remittances as an implicit family loan arrangement. World Development, 25(4), 589-61.

Poirine points out the reality that at times, remittances are seen as an implicit family loan arrangement. It can be used against one another in family debacles in regards to who is helping and who is not helping the family. It can also be seen as a silent agreement in the share of resources where one will send money to help with a family obstacle and then the sender will later ask for something from back home in which the receiver of the remittance will return the favor for the sender by getting something for them. 
Tamasese, T.K., Parsons, T.L., Sullivan, G., \& Waldegrave, C. (2010). A qualitative study into Pacific perspectives on cultural obligations and volunteering. Retrieved from:

http://www.familycentre.org.nz/Publications/PDF's/Cultural\%200bligations\%20and\%2 ovolunteering\%20Main.pdf.

It is often viewed by outsiders that the sense of cultural obligation of Pacific families is extreme. It is often pointed out by the younger generation, how rich Pacific families would be, if not for these obligations to their ever so large families. This research gives the perspective Pacific peoples have in carrying out these duties. These duties often include sending money back home (remittances), giving monetary support in the events of weddings, funerals and birthdays as well as giving up ones time to be present in these events and helping in the background (cooking, washing, cleaning etc.). The findings in here suggest that Pacific peoples see it as "a moral and ethical responsibility to care for, support and assist aiga [family]" (p.198). This obligation is seen as not a matter of choice. To not assist is "seen to be unethical, immoral and non-sacred" (p.198). It is seen as a matter of helping one another and reciprocating this connection.

Thornton, A., Kerslake, M.T., \& Binns, T. (2010). Alienation and obligation: Religion and social change in Samoa. Asia Pacific Viewpoint, 51 (1), 1-16.

This paper is very interesting as it considers religion and social change in Samoa. Thornton, Kerlake \& Binns found that families are no longer putting the church first, but prioritising the well-being of their household. This change they say is due to pressure from overseas Samoan migrants that are highly skilled and very well educated. The authors indicate that the churches are slow in accepting this as the reality. A positive point of this change is that more focus is put upon the well-being of family members and hopefully families will be less in debt due to putting church responsibilities as the top priority. This could mean a brighter future for Pacific families but also a very disruptive one for churches especially the traditional ones.

Tumama Cowley, E., Paterson, J., \& Williams, M. (2010). Traditional gift giving among Pacific families in New Zealand. Journal of Family and Economic Issues, 431444.

For Pacific families, it is traditional to give to the church, not only through monetary means but also goods e.g. printer, computer, traditional weaving such as mats and tapa (bark cloth) etc. This article details the practice of traditional gift giving among Pacific families in New Zealand. An important aspect in this article is the indication that the younger Pacific generation are breaking out from these heavily "money driven" churches and attending ones where it is less obligational but although this trend is occurring, the commitment to these traditional churches are still there. 


\section{Loan Sharks and Debt}

It is not new that Pacific families have been easily getting into debt through the use of the fastest and easiest option at the time when in need of cash - loan sharks. This is often to cover unexpected family obligations which could be a funeral in the family or the urgency to fly back home due to an important family matter. These entries will shed some light on the issue of loan sharks and debt that most Pacific families have encountered.

Anae M, Coxon E, Lima I, Atiga L, Tolley H. (2007). Pacific Consumers' Behaviour and Experience in the Credit Market, With Particular Reference to the 'Fringe Lending' Market. Wellington (NZ): Ministry of Consumer Affairs.

These authors identify the vulnerability of Pacific consumers in getting into financial contracts with super high interest rates and fees, unprotected loans and many more hardships. The authors point to Samoans as having the most trouble with the fringe market due to the Samoan way of giving not only for the family but the church. The Samoan custom called, fa' avalevale is often pointed out as the reason for the need of these loans with long term repercussions. This is the case for many Samoan families but there is a growing contempt amongst the New Zealand born leading to moving against this practice.

Bellringer , M. E., Perese, L. M., Abbott, M. W., \& Williams, M. M. (2006). Gambling Among Pacific Mothers Living in New Zealand. International Gambling Studies, 6(2), 217-235.

A major finding in this research was that those who carry out traditional gift giving customs are likely to spend more money on gambling than those who do not. This was very shocking to me as our Tongan culture is one full of traditional gift giving obligations. The authors believe that with the findings highlighted in their report, there is a need to look into depth in the cultural values and beliefs of Pacific peoples that may affect contemporary Pacific gambling practices. This is similar to the need to family obligations needing to be reduced due to the financial strain it had upon Pacific families.

The Families Commission. (2012). Pacific families and problem debt. Research Report 06: November 2012. Retrieved from

http://www.familiescommission.org.nz/publications/research-reports/pacific-familiesand-problem-debt.

This report highlights the underlying causes of Pacific debt and cultural practices that might contribute to the tendency to get into debt. It is very educational with case studies and interviews with Pacific individuals and families about their financial situations, how their money is spent and the reasons for this. This report is very much up to date and should be sought out if one is seeking to understand the realities Pacific families face with their monetary situation. 
Perese. L. M, Bellringer, M. E., Williams, M. M., \& Abbott, M. W. (2009). Two years on: Gambling amongst Pacific mothers living in New Zealand. Pacific Health Dialog, 15(1), 55-67.

It was found in this research that the findings were very much consistent with their 2006 investigation (Bellringer, Perese, Abbott \& Williams, 2006). There was an additional discovery that those with a low affiliation of cultural identity had an increased likelihood of gambling. Therefore the stronger the affiliation with one's culture, the smaller the probability of getting into gambling. This strong affiliation, the author's state could also serve as a protective mechanism although this is an idea that needs further exploration.

Signal, L., Lanumata, T., \& Bowers, S. (2012). Punching loan sharks on the nose: effective interventions to reduce financial hardship in New Zealand. Health Promotion Journal of Australia, 23(2), 108-111.

This article points out the financial burden upon Pacific families in New Zealand and their obligation to the family (internal, external, village etc.) and the need to reduce this obligation so that these families do not take the easiest way out via loan sharks. Initiatives brought up in this research suggest putting a cap on the fringe lenders (also known as loan sharks) market, the need for financial education and the need for safe, affordable, micro-finance options such as that through the bank. There are needs for the community to work together and these authors call out the church to be enablers in helping these families out of debt, rather than the cause of it.

Tanielu, R., \& Johnson, A. (2013). More than churches, rugby \& festivals: A report on the state of Pasifika people in New Zealand. The Salvation Army Social Policy and Parliamentary Unit: Manukau, New Zealand.

This article, although its main focus is not on loan sharks and debt, does offer an invigorating introduction to the history of the lives of Pacific people in New Zealand starting from when they first prominently arrived here in the 1960's up until now. Tanielu and Johnson do mention loan sharks and debt and they refer readers to the Families Commission Report of 2012. What is interesting is the other facts brought up in this article such as the Pacific unemployment rate, the shift of New Zealanders to Australia and the economy of New Zealand and where the Pacific people are in comparison with other ethnic groups. The authors highlight a major problem of Pacific families as poverty. 


\section{News Articles from the Past 11 Years}

These are a majority of the news articles found online via the internet, from the past 11 years, therefore 2002 up till now, in regards to issues that have come up in the media to do with money, fraud, theft etc. in relation to Pacific people and Pacific churches. There were over 50 articles found during this time span but some had to be cut out due to it relating to the same event or not being relevant to the aims of this bibliography. These annotations have been sorted in order from the latest date, to the earliest.

Radio Australia. (2013, July 3). Troubled Tongan church project in Sydney collapses. Retrieved August 13, 2013, from

http://www.radioaustralia.net.au/international/radio/program/pacificbeat/troubled-tongan-church-project-in-sydney-collapses/1 155788

The church property has been brought by Sant Nirankari Mission, part of an offshoot of the Sikh religion. The significance of this church building was it mirroring the one in Nuku'alofa, the capital of Tonga called Saione. In this article, a Tongan church leader, not belonging to this denomination but was a past member when he was in Tonga, talks to Radio Australia about the loss of this church due to debt. At the time of the interview it coincides with several ministers having to be stood down due to misappropriated church funds. Naikoto (interviewee), talks of the temptation ministers have in dealing with large amounts of money but he also highlights a very crucial point - that the church ministers are very much respected to the point where you do not question them on their motives or anything at all. This respect that comes with the title and "doing God's work", can also lead the sheep astray. Naitoko points out that the church has to monitor the way their leaders handle finance which I agree is vital and in all ways can relate to good recordkeeping practices as you want honesty as well as accountability.

Morrah, M. (2013, June 30). Tongan pastor stood down over alleged threats.

Retrieved August 13, 2013, from

http://www.3news.co.nz/Tongan-pastor-stood-down-over-allegedthreats/tabid/423/articlelD/303248/Default.aspx

The threats that were passed between this pastor and a church member are a result of claims that the pastor was mismanaging church donations which he denies. Money was supposed to be sent to Cambodia to help with missionary work which the church member claims never got there and therefore wanted his money back. The pastor states that he will get proof that this money went through and that money that was under his care for the funding of a church building is still where it is with the church. Records will need to be consolidated to determine whose side of the story is the right one and these records will have to be clean, pure ones and not forged which can happen in these types of cases. The pastor's name can only be cleared if he has proof that he did what he did which it is why it is important to keep a record of transactions and everything you do with money. 
Radio New Zealand. (2013, June 17). Biggest church in Samoa to start lending to its members. Retrieved August 2, 2013, from

http://www.radionz.co.nz/international/pacific-news/212963/biggest-church-insamoa-to-start-lending-to-its-members

"The Congregational Christian Church of Samoa will soon start a loan scheme to help members who need funds to develop their families." After Cyclone Evan, that happened six months ago, this church sets out to do something positive by loaning members money to rebuild their damaged homes and properties. Maybe this is something all churches should do and maybe it should not be a loan but a part of helping? We need more information in regards to the repayment's and interest being made but the article reports that one million USD has been put aside for this cause.

Radio New Zealand. (2013, June 6). Funding for oldest Anglican church approved. Retrieved August 2, 2013, from

http://www.radionz.co.nz/news/regional/137011/funding-for-oldest-anglicanchurch-approved

This shows how the community can be willing to help churches in their times of need especially when it is used abundantly by numerous members of the public.

Radio New Zealand. (2013, May 22). Eight Tonga Free Wesleyan pastors suspended over missing funds. Retrieved August 5, 2013, from

http://www.radionz.co.nz/international/pacific-news/212342/eight-tonga-freeweslyan-church-pastors-suspended-over-missing-funds

There is an estimated 344,000 US dollars missing and the auditor will be going through the records to find out what was done with these funds. Until all is sorted, these pastors will be stood down.

Radio New Zealand International. (2013, May 22). Erring Tonga clergy to be held to account. Retrieved August 5, 2012, from

http://www.rnzi.com/pages/news.php?op=read\&id=76207

This article relates to the importance of recordkeeping because it was found in Tonga, that eight pastors had been misusing funds, and as a result were suspended from duties. Dr Mohenoa Puloka acknowledges the significance of work as a clergy in the church as they are entrusted with the people's money and their job is to use this money appropriately for the church and not their own means.

Wall, T. (2013, January 27). Destiny members quit over spending on church building. Retrieved August 5, 2012, from http://www.stuff.co.nz/auckland/local-news/8228495/Destiny-members-quit-overspending-on-church-building 
This article points out the pressure to donate and come up with funds for church buildings etc. Although it was asked for each family to donate $\$ 1000$ each for the transformation of a warehouse into a church facility, there are still concerns as to who can actually afford this. In times of need people often get desperate and the pressure to donate can lie heavily on the shoulders of each family. This disagreement between members and the church leader results in the loss of church members in the church due to disagreeing with what the leader wants.

Radio New Zealand. (2012, November 26). Church urged to consider Pacific families' financial constraints. Retrieved August 7, 2013, from

http://www.radionz.co.nz/news/national/121827/church-urged-to-consider-pacificfamilies'-financial-constraints

Cultural obligations to the church were found as the main reason for Pacific families struggling financially - this is what is stated by The Families Commission after the release of their report, with these findings. There is a call out for churches to reduce this pressure and for Pacific families to say no.

Radio New Zealand. (2012, November 25). Report examines high debt among Pacific families. Retrieved August 5, 2013, from

http://www.radionz.co.nz/news/national/121780/report-examines-high-debtamong-pacific-families

This article highlights the importance of Pacific families to seek help and take advantage of the services available when they are in too deep with debt and financial problems. The church is encouraged to push their members towards these services.

One News. (2012, November 12). Tongan church leader accused of investing in failed ponzi scheme. Retrieved August 5, 2013, from

http://tvnz.co.nz/world-news/tongan-church-leader-accused-investing-in-failedponzi-scheme-5205625

"A Tongan church president is being urged to resign after he invested funds into a failed investment scheme run by a New Zealander." This particular Tongan church (Tokaikolo) is known for their extravagant money donations not only for within the church but also to the Tongan community and country itself. The auditor states that with this church the president has control of everything including money. At least it is known who is accountable for making this decision but the steps into making these major types of decisions should include the congregation and their thoughts as well as having a good financial adviser for these types of investments. This just shows the dedication of the people to their church and their leaders that they would just go with whatever is being done without at times, being able to voice an opinion or go

Radio New Zealand. (2012, September 25). Dwindling congregation forces $\$ 1 \mathrm{~m}$ church sale. Retrieved 1 August, 2013, from 
http://www.radionz.co.nz/news/regional/1 16486/dwindling-congregation-forces$\$ 1 \mathrm{~m}$-church-sale

Sadly this could be the case, although it does not have anything to do with the Pacific people, this just goes to show how important it is to have members in the church so that its possession can be maintained. Without members or the lack thereof, this is what can happen.

Radio New Zealand. (2012, August 16). Pacific migrants resent church group money drives. Retrieved August 5, 2013, from

http://www.radioaustralia.net.au/international/2012-08-15/pacific-migrants-resentchurch-group-money-drives/1000010

Often the case with this is that migrants are migrating to make a better future for themselves and their immediate family. Then these fundraising drives come along which defeats the purpose of the reason they are there. There is pressure to donate to these groups and it is a cultural thing to help one another and especially back home in the islands.

Radio New Zealand. (2012, July 6). Samoa churches warn against planned casinos. Retrieved August 5, 2013, from

http://www.radionz.co.nz/international/pacific-news/205718/samoa-churches-warnagainst-planned-casinos

Samoa National Council of Churches have spoken out to the Prime Minister of Samoa about their fears of having casino's in the country. This is fear of the people saving up to go play in there instead of feeding their families therefore leading to more poverty within the nation. There are already existing problems with Pacific families and gambling and by having the casino's there it will just increase this bad habit that is already developing.

Mckenny, L. (2012, January 28). Tonga's church, built in hope, faith and pride, collapses in debt. Retrieved August 5, 2013, from

http://www.smh.com.au/national/tongas-church-built-in-hope-faith-and-pridecollapses-in-debt-20120127-1 almv.html

This church was in over 18 million dollars of debt resulting in it having to be taken away from the community and its owners - The Free Wesleyan Church of Tonga in Australia. What stood out in this article was the "degree of financial naivety", as mentioned by one of them that financed the 10 million dollars required for this building project. What are obviously needed are policies and regulations within church groups/denominations to look into these types of projects so that they can determine the success of such a project within the means of the church and community. Good recordkeeping practices would have helped in keeping on top of payments for the loans as well as ensuring that the right information is processed and passed on. This article is an example of how important financial advisers and recordkeeping is in the running of a church congregation so that money is not lost or 
all for nothing like the 3 million dollars these church members and people of the community.

Radio New Zealand. (2012, January 17). Lavish ceremonies driving Samoans to steal, says employer. Retrieved August 5, 2013, from

http://www.radionz.co.nz/international/pacific-news/201995/lavish-ceremoniesdriving-samoans-to-steal,-says-employer

It is mentioned here that there is a competition amongst locals to splash out on the lavish gifts for wedding/birthday/church function etc. One employer says in here that it all starts from home and that burden to outdo one another is causing havoc in items going missing or being stolen.

Radio New Zealand. (2011, January 7). Fiji Methodists consider tourism investment. Retrieved August 5, 2013, from

http://www.radionz.co.nz/international/pacific-news/194671/fiji-methodists-considertourism-investment

This is a positive story, of the Fji Methodist church taking careful consideration of whether the church's money should be invested in this tourism project. At least they are not rushing into it and evaluating whether their money should go into such a deal.

Radio New Zealand. (2010, December 6). Former church minister in Samoa jail for false pretence over visa. Retrieved from August 5, 2013, from http://www.radionz.co.nz/international/pacific-news/194133/former-churchminister-in-samoa-jail-for-false-pretence-over-visa

It is sad to see or hear of our own Pacific peoples taking advantage of their own. Authorities should be called upon if one is feeling this case and although it can be shaming to have something like this happen, it is also a good way to notify others in the community of what this person has done.

Radio New Zealand. (2010, June 23). Church returns some money to disabled man. Retrieved August 5, 2013, from

http://www.radionz.co.nz/news/national/34174/church-returns-some-money-todisabled-man

Taking from the poor/disabled is an act that churches have to be aware of as it is seen from outsiders as wrong.

Radio New Zealand. (2010, April 27). Samoan church minister's wife stands trial on forgery and theft charges. Retrieved August 5, 2013, from

http://www.radionz.co.nz/international/pacific-news/189964/samoan-churchminister's-wife-stands-trial-on-forgery-and-theft-charges

It is very unfortunate that such a person, one seen in the eyes of the village as trustworthy and the wife of a minister, is taking advantage of their money and 
pocketing it for herself. This shows the ease of trust Pacific communities have in the church and the people of the church as they have major respect for the minister and his family.

Radio New Zealand. (2010, January 16). Church minister denies offering residency permits to Fijians. Retrieved August 6, 2013, from

http://www.radionz.co.nz/international/pacific-news/188230/church-minister-deniesoffering-residency-permits-to-fiijians

This minister claims to be trying to help the people and not taking money from them although he does take a couple of dollars ( $\$ 10$ or $\$ 20$ ) here and there if offered but does that still make it alright?

Radio New Zealand. (2009, July 6). Worship center church in Samoa to establish financial investment company. Retrieved August 6, 2013, from

http://www.radionz.co.nz/international/pacific-news/184619/worship-center-churchin-samoa-to-establish-financial-investment-company

Churches' turning themselves into financial institutions is encouraging but I also find this apprehensive as it is the money of the church members being used to invest and hopefully they have proper procedures in how this all turns out. There is a selection of church members are on the board and hopefully that ensures all records are kept with what is done with these funds for the mission of the church, especially with going overseas.

Radio New Zealand. (2007, October 3). Samoan consulate employee in Auckland loses job after probe into missing funds. Retrieved August 6, 2013, from http://www.radionz.co.nz/international/pacific-news/173053/samoan-consulateemployee-in-auckland-loses-job-after-probe-into-missing-funds

A minister's wife, employed in the Samoa Consulate General office Auckland had lost her job after it was found that around $\$ 150,000$ US dollars was missing from the office as well as a misappropriation of funds. An audit was conducted and it shows how important records are in showing the truth of transactions. Although this does not have much to do with the church, this is a minister's wife that was investigated.

Radio New Zealand. (2007, August 29). Fiji Methodists shun regime over lack of democracy. Retrieved August 6, 2013, from

http://www.radionz.co.nz/international/pacific-news/172323/fiij-methodists-shunregime-over-lack-of-democracy

This church owes money to the government but they are refusing to pay due to those in power, have taken it illegally and would rather see a government in power that has been elected by the people. This sheds light on the relationship the church has with the state and at times it can be a conflicting one.

Radio New Zealand. (August 16, 2007). Samoa PM reminds church ministers of the principles of good governance. Retrieved August 11, 2013, from 
http://www.radionz.co.nz/international/pacific-news/172006/samoa-pm-remindschurch-ministers-of-the-principles-of-good-governance

Prime Minister, Tuila'epa Sa'ilele Malielegaoi, recommends that Church minister's stay away from managing the finances of their church and ought to leave it to the followers in their congregation who are qualified at doing so. He also states to the leaders and future ones that the principles of good governance such as transparency and accountability are imperative to uphold.

Radio New Zealand. (2007, April 30). Three bank employees in American Samoa questioned over missing funds. Retrieved August 12, 2013, from http://www.radionz.co.nz/international/pacific-news/169489/three-bankemployees-in-american-samoa-questioned-over-missing-funds

This does not have anything to do with a church but it is a case of funds missing.

Radio New Zealand. (2006, August 16). Solomons bishop probed for fund abuse. Retrieved August 12, 2013, from

http://www.radionz.co.nz/international/pacific-news/164069/solomons-bishopprobed-for-fund-abuse

This case shows the important factor that records play in the up keeping of accountability and transparency. By keeping records, it allows for someone to go through them and balance the books and prove if this bishop did or did not misuse funds.

Radio New Zealand. (2005, July 13). Cooks police warn people about email scammer targeting Christians. Retrieved August 12, 2013, from

http://www.radionz.co.nz/international/pacific-news/156226/cooks-police-warnpeople-about-email-scammer-targeting-christians

This does not only happen in the Pacific but also all over the world. At least with this case, the police are getting out there and the community is notified of this problem. It is easy to see why Christians are targets as they believe in giving to good causes but there are times when they are taken advantage of and they should know of this.

Radio New Zealand. (2005, January 14). Former Methodist leader in Fiji blames church for crime jump. Retrieved August 12, 2013, from

http://www.radionz.co.nz/international/pacific-news/152718/former-methodistleader-in-fiji-blames-church-for-crime-jump

The title of this article is one part of it, the other one is about the religious leaders cheating their congregations of money. They are describes as being, "overfed, welldressed and pompous religious dignitaries" whilst their congregations are poor by the burden to uphold the lifestyles of these leaders. This can be seen all over the pacific and is sadly not uncommon. 
Radio New Zealand. (2004, August 28). Fiji Methodists accused of committing financial suicide. Retrieved August 12, 2013, from

http://www.radionz.co.nz/international/pacific-news/150410/fiji-methodistsaccused-of-committing-financial-suicide

An issue often brought up about church members and their donations is who their priority should be - the church or the necessities for their families to survive. The pressure to donate and to donate a lot can be at times, such a heavy burden in these Pacific churches.

Radio New Zealand. (2004, July 15). Methodist Church in Fiji rejects claims ministers take church funds for personal use. Retrieved August 12, 2013, from

http://www.radionz.co.nz/international/pacific-news/149644/methodist-church-in-fiijrejects-claims-ministers-take-church-funds-for-personal-use

This is another case of yet the same allegations already mentioned here before of pastors using the generosity of their members for their own personal benefits. By keeping records of how money is spent, the church members are better informed with what their funds are used for so that outsiders and also those within the group do not make "false" accusations against them.

Radio New Zealand. (2003, October 17). Fiji Churches condemn money scam for missions work. Retrieved August 12, 2013, from

http://www.radionz.co.nz/international/pacific-news/145778/fiji-churchescondemn-money-scam-for-missions-work

The Reverend interviewed for this article points out the role of the church to serve the people and that money is secondary, although there have been cases of churches all about the money and sadly that has resulted in many people getting hurt and loosing what they believe to be a safety net for their donated funds.

Radio New Zealand. (2003, August 13). Fiji's Methodists call for control of new Christian churches. Retrieved August 12, 2013, from

http://www.radionz.co.nz/international/pacific-news/144820/fiji's-methodists-call-forcontrol-of-new-christian-churches

At the end of this article, an issue is brought up about churches competing for followers and their money. This is very concerning as it shows another side of churches that is not ideal but very real in some parts of the Pacific especially with the ideals of new churches and faith's coming into the region.

Radio New Zealand. (2003, February 24). Samoan church in Hawaii loses funds to fraudster. Retrieved August 12, 2013, from

http://www.radionz.co.nz/international/pacific-news/142560/samoan-church-inhawaii-loses-funds-to-fraudster

Churches have to be aware and very careful of fraudster's or anyone they give the use of their money to. Background checks should be conducted on people and 
their advice. This church was promised 6 million dollars from the sixty thousand they gave and in the end it was all just a scheme to get money from them.

Radio New Zealand. (2002, August 22). Call for an audit into Fiji's Methodist Church's finances gathers strength. Retrieved August 12, 2013, from

http://www.radionz.co.nz/international/pacific-news/140567/call-for-an-audit-intofiji's-methodist-church's-finances-gathers-strength

This article mentions the pressures of families to donate funds to the church, resulting in families going into debt and at times leaving their villages to elude the embarrassment caused by Minister's reading out donation name and amounts to the congregation, at the time of the service. The yearly amounts some churches come up with is so big (2 million in one provenance), that records of where or what that money is spent on is a very important factor.

Radio New Zealand. (2002, May 3). EU warns Fiji not to use money for development on land acquisition. Retrieved August 12, 2013, from

http://www.radionz.co.nz/international/pacific-news/139320/eu-warns-fiji-not-to-usemoney-for-development-on-land-acquisition

This news article points out the involvement of foreign countries in the Pacific by donating money for aid, which is also very worrisome as they (donator's) can control what that money can be used for. In this case, the European Union are the ones that have donated and the Methodist Church is demanding a part of that money for a project.

\section{Conclusion}

Pacific people are a unique group of people with an unwavering devotion to their cultural obligations whether it is for the family or for the church. The cultural ties with the church and the impact it has on their daily lives are shown in this research. The pressure to donate and give all to the church is a very realistic occurrence which at times can lead to Pacific families getting into debt by taking on the easiest way out through the use of loan sharks that have additional hidden costs (interest, penalties, extra fees etc.). There is pressure to send money back home to family members and these remittances are known to be heavily relied upon not only for the general wellbeing of households but the status of one amongst the village group.

It is obvious that Pacific people lack knowledge about archives and records management. There is a strong need for rules and regulations to be implemented in both the governmental and church associations in order to keep track of the distribution and use of resources. By educating the people and raising awareness through church and community led programs, Pacific people will be able to prevent and safeguard themselves from being exposed to unethical forms of conduct that is 
not only happening within the church but also in work places and social surroundings today.

\section{Index}

Access

Accountability

Archives

Business

Church

Colonial

Congregation

Cook Islands

Dance

Debt/s

Digital divide

Finance

Fraud

Funds

Education

Fiji

Gambling

Governance

Government

Hawai'i

History

Indigenous

Kiribati

Loan/s

Memory

Migration

Minister (Church)

Missionary/ies

Money

Museum

Pastor

Oral traditions

Papua New Guinea

Sound/Recordings

Record/s

Recordkeeping

Remittances

Samoa
$13,14,16$

$11,12,16,17,18,19,26,32$

$4,7,8,9,10,11,12,13,14,15,17,33$

$5,8,19$

$4,5,7,10,15-33$

$7,9,12,14,18$

$26,27,28,31,32,33$

$5,21,22,31$

$10,12,16.18$

$3,5,7,22,23,24,25,27,28,35$

12

$24,25,28,31$

32

$8,13,15,25,26,27,30,31,32,33$

$7,8,10,11,14,19,20,23,24$

$5,8,9,11,12,14,20,21,29,30,31,32,33$

$23,24,28$

$8,10,11,19,31,32$

$7,8,10,11,12,30,33$

$10,14,33$

$7,9,10-20,25$

$11,13,14,15,16$

$5,11,19$

$4,5,7,20,21,24,26,28,33$

$4,7,11,13$

$20,21,29$

$4,25,28,29,30,31,32,33$

$7,8,10,18,25$

$4,5,17-19,21-23,25-33$

9,12

$20,25,26,32$

$7,9,11,12,14,16,22$

5,11

$13,14,18$

$5-13,15,19,26,27,31,32,33,34$

$4-13,15,16,17,18,19,25,26,28$

$4,5,7,19,20,21,22$

$5,20,21,22,23,26,28.29,30,31,32$ 
Scam

Scheme

Secrecy

Solomon Islands

Technology

Tonga

Training

Transaction

Tuvalu
31,32

$27,28,33$

34

5,31

$7,8,12,13,15$

$5,10,12,18,20,21,23,25,26,27,28$

$7,8,10,11$

$5,26,31$

$5,19$. 


\section{References}

Anae M, Coxon E, Lima I, Atiga L, Tolley H. (2007). Pacific Consumers' Behaviour and Experience in the Credit Market, With Particular Reference to the 'Fringe Lending' Market. Wellington (NZ): Ministry of Consumer Affairs.

Basri, H., \& Khalid, S.N.A. (2012). Examining accounting and accountability issues in religious context: Insights from literature. Aceh International Journal of Social Sciences, $1(1), 24-31$.

Bellringer, M. E., Perese, L. M., Abbott, M. W., \& Williams, M. M. (2006). Gambling Among Pacific Mothers Living in New Zealand. International Gambling Studies, 6(2), 217-235.

Boland, S., \& Doller, B. (2005). The economic significance of migration and remittances in Tuvalu, 1-37.

Borovnik, M. (2006). Working overseas: Seafarers' remittances and their distribution in Kiribati. Asia Pacific Viewpoint, 47(1), 151-161.

Brown, R.P.C, \& Ahlburg, D.A. (1999). Remittances in the South Pacific. International Journal of Social Economics, 26 (1/2/3), 325-344.

Brown, R. P. C., Leeves, G., \& Prayaga, P. (2012). An analysis of recent survey data on the remittances of Pacific island migrants in Australia. .1-41.

Brown, R. P. C., Connell, J. \& Jimenez-Soto, E. V. (2013). Migrants' Remittances, Poverty and Social Protection in the South Pacific: Fiji and Tonga. Wiley Online Library, 0-20.

Cafardi, N. P. (1993). Discovering the Secret Archives: Evidentiary Privileges for Church Records. Journal of Law and Religion, 10(1), 95-120.

Carmona, S., \& Ezzamel, M. (2006). Accounting and religion: a historical perspective. Accounting History, $11,117-127$.

Carnegie, G.D., \& Napier, C.J. (2012). Accounting's past, present and future: the unifying power of history. Accounting, Auditing \& Accountability Journal, 25(2), 328-369.

Cohen, A. (2011). Pacific Islands Association of Libraries and Archives (PIALA). In (EDITORS NAMES Eds.) Encyclopedia of Library and Information Sciences, (3rd ed. , pp. 4095-4105). Retrieved from Taylor \& Francis Online database.

Connell, J., \& Conway, D. (2000). Migration and remittances in island microstates: A comparative perspective on the South Pacific and the Caribbean. International Journal of Urban and Regional Research, 24(1), 52-78. 
Conrad, A. C. (1967). The archives of Hawaii. The Journal of Pacific History, 2, 191197.

Crookstan, M. (2011). Raising the standard of recordkeeping in the Pacific: The PARBICA recordkeeping for good governance toolkit. Comma, 2011 (2): International Journal on Archives, 111-121.

Crookston, M. (2011). Record keeping for good governance in the Pacific: The work of the Pacific regional branch of the international council on archives. Archifacts, 73-83.

Cummins, H. G. (1978). The archives of the Free Wesleyan Church of Tonga. The Journal of Pacific History, 13(2), 102-106.

Cunningham, A., \& Wareham, E. (2011). Introduction communities of memory: Ideas from the islands on refiguring archival identities. Comma, 2011 (1): International Journal on Archives, 1-4.

The Families Commission. (2012). Pacific families and problem debt. Research Report 06: November 2012. Retrieved from

http://www.familiescommission.org.nz/publications/research-reports/pacific-familiesand-problem-debt.

Gilliland, A., McKemmish, S., White, K., Lu, L., \& Lau, A. (2008). Pluralizing the Archival Paradigm: Can Archival Education in Pacific Rim Communities Address the Challenge?. The American Archivist, 71, 87-117.

Gordon-Clark, M. (2012). Paradise lost? Pacific island archives threatened by climate change. Archival Science, 12(1), 51-67.

Hoyle, M., \& Millar, L. (2004). The challenge of records and archives education and training in the pacific. Archives \& Manuscripts, 32(2), 114-141.

Hugo, G. (2012). Migration and development in low-income countries: a role for destination country policy?. Migration and Development, 1 (1), 24-49.

Irvine, $H$. (2004). Balancing money and mission in a local church budget. Accounting, Auditing \& Accountability Journal, 18(2), 21 1-237.

Jimenez-Soto, E., \& Brown, R.P.C. (2012). Assessing the poverty impacts of migrants' remittances using propensity score matching: The case of Tonga. The Economic Record, 88(282), 425-439.

Leardini, C., \& Rossi, G. (2013). Accounting and power in religious institutions: Verona's Santa Maria della Scala monastery in the Middle Ages. Accounting History, 18, 415-427.

Kaima, S. (1999). Education and training for archivists and record keepers in the Pacific. Information Development, 15(1), 51-55. 
Kaima, S.T. (2000). Rekot bilong masta: Archives and records management in Papua New Guinea. Information Development, 16(1), 37-43.

Kempf, W. (2012). Promised land in the diaspora: Christian religion, social memory, and identity among Banabans in Fiji. Pacific Studies, 35(112), 90-1 18.

Laracy, E., \& Laracy, H. (1979). Archives of the Catholic Diocese of Tonga. The Journal of Pacific History, 4 (4), 221-224.

Laracy, E., \& Laracy, H. (1979). Archives of the Marist Province of Oceania. The Journal of Pacific History, 14 (4), 224-227.

Laughlin, R. (1988). Accounting in its social context: An analysis of the accounting systems in the Church of England. Accounting, Auditing \& Accountability Journal, 1 (2), 19-42.

Le De, L., Gaillard, G.C., \& Friesen, W. (2013). Remittances and disaster: A review. International Journal of Disaster Risk Reduction, 4, 34-43.

Macpherson, C., \& Macpherson, L. (2011). Churches and the economy of Samoa. The Contemporary Pacific, 23(2), 303-338.

Maidment, E. (2001). Fiji museum archives and manuscripts collection. The Journal of Pacific History, 36 (2), 237-246.

Marsters, E., Lewis. N., \& Friesen, W. (2006). Pacific flows: The fluidity of remittances in the Cook Islands. Asia Pacific Viewpoint, 47(1), 31-44.

McKemmish, S., Faulkhead, S., \& Russell, L. (2011). Distrust in the archive: Reconciling records. Archival Science, 11, 211-239.

Mckenny, L. (2012, January 28). Tonga's church, built in hope, faith and pride, collapses in debt. Retrieved August 5, 2013, from

http://www.smh.com.au/national/tongas-church-built-in-hope-faith-and-pridecollapses-in-debt-20120127-1 glmv.html

McPhail, K., Gorringe, T., \& Gray, R. (2004). Accounting and theology: An introduction. Accounting, Auditing \& Accountability Journal, 17(3), 320-326.

Millar, L. (2003). Education and training for records and archives management in pacific island nations (a needs assessment and report prepared for PABRICA). Retrieved from PABRICA:

http://www.parbica.org/content/DistanceEducationProjectReport tcm50-74752.pdf

Miller, K.C. (2009). Sound ethics for data repositories: The selectedWorks of Kevin

C. Miller. Retrieved from http://works.bepress.com/kevin miller/4

Morrah, M. (2013, June 30). Tongan pastor stood down over alleged threats. Retrieved August 13, 2013, from 
http://www.3news.co.nz/Tongan-pastor-stood-down-over-alleged-

threats/tabid/423/articlelD/303248/Default.aspx

Mortreux, C. \& Barnett, J. (2009). Climate change, migration and adaptation in Funafuti, Tuvalu. Global Environmental Change, 19, 105-112.

Newman, J. (2012). Sustaining community archives. Comma, 2011 (1): International Journal on Archives, 89-102.

One News. (2012, November 12). Tongan church leader accused of investing in failed ponzi scheme. Retrieved August 5, 2013, from

http://tvnz.co.nz/world-news/tongan-church-leader-accused-investing-in-failedponzi-scheme-5205625

Perese. L. M, Bellringer, M. E., Williams, M. M., \& Abbott, M. W. (2009). Two years on: Gambling amongst Pacific mothers living in New Zealand. Pacific Health Dialog, 15(1), 55-67.

Poirine, B. (1997). A theory of remittances as an implicit family loan arrangement. World Development, 25(4), 589-61.

Paisey, C., \& Paisey, N.J. (2011). Visibility, governance and social context: Financial management in the Pre-Reformation Scottish church. Accounting, Auditing \& Accountability Journal, 24 (5), 587-621.

Radio Australia. (2013, July 3). Troubled Tongan church project in Sydney collapses. Retrieved August 13, 2013, from

http://www.radioaustralia.net.au/international/radio/program/pacific-

beat/troubled-tongan-church-project-in-sydney-collapses/11 155788

Radio New Zealand. (2002, May 3). EU warns Fiji not to use money for development on land acquisition. Retrieved August 12, 2013, from

http://www.radionz.co.nz/international/pacific-news/139320/eu-warns-fiji-not-to-usemoney-for-development-on-land-acquisition

Radio New Zealand. (2002, August 22). Call for an audit into Fiji's Methodist Church's finances gathers strength. Retrieved August 12, 2013, from

http://www.radionz.co.nz/international/pacific-news/140567/call-for-an-audit-intofiji's-methodist-church's-finances-gathers-strength

Radio New Zealand. (2003, February 24). Samoan church in Hawaii loses funds to fraudster. Retrieved August 12, 2013, from

http://www.radionz.co.nz/international/pacific-news/142560/samoan-church-inhawaii-loses-funds-to-fraudster

Radio New Zealand. (2003, August 13). Fiji's Methodists call for control of new Christian churches. Retrieved August 12, 2013, from

http://www.radionz.co.nz/international/pacific-news/144820/fiji's-methodists-call-forcontrol-of-new-christian-churches 
Radio New Zealand. (2003, October 17). Fiji Churches condemn money scam for missions work. Retrieved August 12, 2013, from

http://www.radionz.co.nz/international/pacific-news/145778/fiji-churches-condemnmoney-scam-for-missions-work

Radio New Zealand. (2004, August 28). Fiji Methodists accused of committing financial suicide. Retrieved August 12, 2013, from

http://www.radionz.co.nz/international/pacific-news/150410/fiji-methodistsaccused-of-committing-financial-suicide

Radio New Zealand. (2004, July 15). Methodist Church in Fiji rejects claims ministers take church funds for personal use. Retrieved August 12, 2013, from

http://www.radionz.co.nz/international/pacific-news/149644/methodist-church-in-fiijrejects-claims-ministers-take-church-funds-for-personal-use

Radio New Zealand. (2005, January 14). Former Methodist leader in Fiji blames church for crime jump. Retrieved August 12, 2013, from

http://www.radionz.co.nz/international/pacific-news/152718/former-methodistleader-in-fiji-blames-church-for-crime-jump

Radio New Zealand. (2005, July 13). Cooks police warn people about email scammer targeting Christians. Retrieved August 12, 2013, from

http://www.radionz.co.nz/international/pacific-news/156226/cooks-police-warnpeople-about-email-scammer-targeting-christians

Radio New Zealand. (2006, August 16). Solomons bishop probed for fund abuse. Retrieved August 12, 2013, from

http://www.radionz.co.nz/international/pacific-news/164069/solomons-bishopprobed-for-fund-abuse

Radio New Zealand. (2007, April 30). Three bank employees in American Samoa questioned over missing funds. Retrieved August 12, 2013, from

http://www.radionz.co.nz/international/pacific-news/169489/three-bankemployees-in-american-samoa-questioned-over-missing-funds

Radio New Zealand. (2007, August 16). Samoa PM reminds church ministers of the principles of good governance. Retrieved August 11, 2013, from

http://www.radionz.co.nz/international/pacific-news/172006/samoa-pm-remindschurch-ministers-of-the-principles-of-good-governance

Radio New Zealand. (2007, August 29). Fiji Methodists shun regime over lack of democracy. Retrieved August 6, 2013, from

http://www.radionz.co.nz/international/pacific-news/172323/fiji-methodists-shunregime-over-lack-of-democracy

Radio New Zealand. (2007, October 3). Samoan consulate employee in Auckland loses job after probe into missing funds. Retrieved August 6, 2013, from 
http://www.radionz.co.nz/international/pacific-news/173053/samoan-consulateemployee-in-auckland-loses-job-after-probe-into-missing-funds

Radio New Zealand. (2009, July 6). Worship center church in Samoa to establish financial investment company. Retrieved August 6, 2013, from

http://www.radionz.co.nz/international/pacific-news/184619/worship-center-churchin-samoa-to-establish-financial-investment-company

Radio New Zealand. (2010, January 16). Church minister denies offering residency permits to Fijians. Retrieved August 6, 2013, from

http://www.radionz.co.nz/international/pacific-news/188230/church-minister-deniesoffering-residency-permits-to-fijians

Radio New Zealand. (2010, April 27). Samoan church minister's wife stands trial on forgery and theft charges. Retrieved August 5, 2013, from

http://www.radionz.co.nz/international/pacific-news/189964/samoan-churchminister's-wife-stands-trial-on-forgery-and-theft-charges

Radio New Zealand. (2010, June 23). Church returns some money to disabled man. Retrieved August 5, 2013, from

http://www.radionz.co.nz/news/national/34174/church-returns-some-money-todisabled-man

Radio New Zealand. (2010, December 6). Former church minister in Samoa jail for false pretence over visa. Retrieved from August 5, 2013, from http://www.radionz.co.nz/international/pacific-news/194133/former-churchminister-in-samoa-jail-for-false-pretence-over-visa

Radio New Zealand. (2011, January 7). Fiji Methodists consider tourism investment. Retrieved August 5, 2013, from

http://www.radionz.co.nz/international/pacific-news/194671/fiji-methodists-considertourism-investment

Radio New Zealand. (2012, January 17). Lavish ceremonies driving Samoans to steal, says employer. Retrieved August 5, 2013, from

http://www.radionz.co.nz/international/pacific-news/201995/lavish-ceremoniesdriving-samoans-to-steal,-says-employer

Radio New Zealand. (2012, November 25). Report examines high debt among Pacific families. Retrieved August 5, 2013, from http://www.radionz.co.nz/news/national/121780/report-examines-high-debtamong-pacific-families

Radio New Zealand. (2012, November 26). Church urged to consider Pacific families' financial constraints. Retrieved August 7, 2013, from

http://www.radionz.co.nz/news/national/121827/church-urged-to-consider-pacificfamilies'-financial-constraints 
Radio New Zealand. (2012, July 6). Samoa churches warn against planned casinos. Retrieved August 5, 2013, from

http://www.radionz.co.nz/international/pacific-news/205718/samoa-churches-warnagainst-planned-casinos

Radio New Zealand. (2012, August 16). Pacific migrants resent church group money drives. Retrieved August 5, 2013, from

http://www.radioaustralia.net.au/international/2012-08-15/pacific-migrants-resentchurch-group-money-drives/1000010

Radio New Zealand. (2012, September 25). Dwindling congregation forces $\$ 1 \mathrm{~m}$ church sale. Retrieved 1 August, 2013, from

http://www.radionz.co.nz/news/regional/116486/dwindling-congregation-forces-

$\$ 1 \mathrm{~m}$-church-sale

Wall, T. (2013, January 27). Destiny members quit over spending on church building. Retrieved August 5, 2012, from

http://www.stuff.co.nz/auckland/local-news/8228495/Destiny-members-quit-overspending-on-church-building

Radio New Zealand. (2013, May 22). Eight Tonga Free Wesleyan pastors suspended over missing funds. Retrieved August 5, 2013, from

http://www.radionz.co.nz/international/pacific-news/212342/eight-tonga-freeweslyan-church-pastors-suspended-over-missing-funds $\backslash$

Radio New Zealand International. (2013, May 22). Erring Tonga clergy to be held to account. Retrieved August 5, 2012, from

http://www.rnzi.com/pages/news.php?op=read\&id=76207

Radio New Zealand. (2013, June 6). Funding for oldest Anglican church approved. Retrieved August 2, 2013, from

http://www.radionz.co.nz/news/regional/137011/funding-for-oldest-anglican-

church-approved.

Radio New Zealand. (2013, June 17). Biggest church in Samoa to start lending to its members. Retrieved August 2, 2013, from

http://www.radionz.co.nz/international/pacific-news/212963/biggest-church-insamoa-to-start-lending-to-its-members

Rixon, D., \& Faseruk, A. (2012). Secular tools and sacred goals: A case study of how Anglican priests are embracing management accounting and strategic planning. Journal of Business Diversity, 12(1), 19-32.

Ryan, J. G. (2001). Irish Church Records: Their History, Availability, and Use in Family and Local History Research. Flyleaf Press: Dublin, Ireland.

Saunders. T \& Terrell, J. (2000). Pacific history bibliography 2000. The Journal of Pacific History, 35(3), 335-376. 
Seles, A. (2006). What are these among so many? Pre and post Vatican II recordkeeping. Archival Science, 6, 393-405.

Signal, L., Lanumata, T., \& Bowers, S. (2012). Punching loan sharks on the nose: effective interventions to reduce financial hardship in New Zealand. Health Promotion Journal of Australia, 23(2), 108-111.

Sweeney, S. (1986). Sheep that have gone astray?: Church record keeping and the Canadian archival system. Archivaria, 23, 54-68.

Tale, S. (2012). Canoeing in cyberspace: Recordkeeping in the Pacific - a Fiji case study. Comma, 2011 (1): International Journal on Archives, 45-50.

Tale, S. (2012). Memory of the world: The Pacific perspective. Comma, 201 1(1): International Journal on Archives, 73-78.

Tamasese, T.K., Parsons, T.L., Sullivan, G., \& Waldegrave, C. (2010). A qualitative study into Pacific perspectives on cultural obligations and volunteering. Retrieved from:

http://www.familycentre.org.nz/Publications/PDF's/Cultural\%200bligations\%20and\%2 OVolunteering\%20Main.pdf.

Tanielu, R., \& Johnson, A. (2013). More than churches, rugby \& festivals: A report on the state of Pasifika people in New Zealand. The Salvation Army Social Policy and Parliamentary Unit: Manukau, New Zealand.

Thornley, A.W. (1977). Methodist mission papers in the National Archives of Fiji, Suva. The Journal of Pacific History, 12 (4), 202-204.

Thornton, A., Kerslake, M.T., \& Binns, T. (2010). Alienation and obligation: Religion and social change in Samoa. Asia Pacific Viewpoint, 51 (1), 1-16.

Tough, A. G. (2012). Oral culture, written records and understanding the twentiethcentury colonial archive. The significance of understanding from within. Archival Science, 12(1), 245-265.

Tumama Cowley, E., Paterson, J., \& Williams, M. (2010). Traditional gift giving among Pacific families in New Zealand. Journal of Family and Economic Issues, 431444.

Wareham, E. (2012). From explorers to evangelists: Archivists, recordkeeping, and remembering in the Pacific Islands. Comma, 2011 (1): International Journal on Archives, 29-44.

Wehner, M., \& Maidment, E. (1999). Ancestral voices: Aspects of archives administration in Oceania. Archives and Manuscripts, 27(1), 22-41.

White, L.K., \& Gilliland, J.A. (2010). Promoting reflexivity and inclusivity in archival education, research, and practice. The Library Quarterly, 80 (3), 231-248. 
Wickman, D. (2012). Recordkeeping legislation and its impacts: the PARBICA recordkeeping for good governance toolkit. Comma, 2011 (1): International Journal on Archives, 51-59.

\section{Bibliography}

Archives New Zealand. (2006). Fact Sheet: "Make a Record". Retrieved from http://archives.govt.nz/fl-make-record.

Kennedy, J. \& Schauder, C. (1998). The records life cycle model and the records continuum model. In Records management: A guide to corporate recordkeeping (2nd ed., 9-12). Melbourne: Addison Wesley Longman.

Pearce-Moses, R. (2005). A Glossary of Archival and Records Terminology. Retrieved from http://files.archivists.org/pubs/free/SAA-Glossary-2005.pdf. 